\title{
EVOLUTION AND IDENTIFICATION OF SOME DATE PALM (PHOENIX DACTYLIFERA L.) CULTIVARS GROWN IN THE EL- DAKHLA OASIS, EGYPT
}

\author{
SALAMA, M. I. ${ }^{1}$ - OMAR, A. K. ${ }^{1}$ - El-MORSY, A. A. ${ }^{1}-$ OMAR, A. A. ${ }^{1,2^{*}}-$ AlAMELDEIN, S. M. ${ }^{3}-$ \\ ALY, K. M. ${ }^{4}$ \\ ${ }^{1}$ Kafresheikh University, Faculty of Agriculture, Horticulture Dept., Kafr El-Sheikh 33516, Egypt \\ ${ }^{2}$ Institute of Research and Consulting, King Faisal University, Hofuf, Kingdom of Saudi Arabia \\ ${ }^{3}$ Horticulture Department, Faculty of Agriculture, Tanta University, Tanta 31527, Egypt \\ ${ }^{4}$ Date Palm Research and Development, Agricultural Research Center, Giza, Egypt \\ *Corresponding author \\ e-mail: alaa.omr@agr.kfs.edu.eg,akomar@kfu.edu.sa; phone:+20-109-740-8240 \\ (Received 13 ${ }^{\text {th }}$ Apr 2019; accepted $19^{\text {th }}$ Jun 2019)
}

\begin{abstract}
This study was carried out during two consecutive seasons on five date palm cultivars grown under the "environmental conditions". of El- Dakhla oasis, New Valley governorate, Egypt. Five date palm cultivars (Bartamoda, Sakoty, Soltany, Sewy and Barhy) were evaluated using morphological characteristics as well as inter- simple sequence repeats (ISSR) as DNA fingerprinting. Results revealed that, Barhy had the highest values through most of the study, it obtained the highest values in leaflet area (161.59 and $\left.176.70 \mathrm{~cm}^{2}\right)$, fruit weight (15.23 and $16.33 \mathrm{~g}$ ), flesh weight (13.89 and $\left.14.99 \mathrm{~g}\right)$, flesh percentage (91.11 and 91.76\%), number of bunches (18.8 and 18.66) and yield/palm (195.4 and $197.21 \mathrm{~kg}$ ). In this study, the total number of ISSR bands were 52 bands, 31 bands were polymorphic "59.61\%" and 21 bands were monomorphic " $40.38 \%$ ". The polymorphic bands contained 20 unique bands, these unique bands could be used to "discriminate" between the studied five date palm cultivars.

Keywords: RAPD, morphological characteristics, DNA, ISSR
\end{abstract}

\section{Introduction}

Dates are dioecious perennial monocotyledon fruit trees that belong to the Arecaceae family. Date palm (Phoenix dactylifera L.) is one of the most important and oldest fruit trees cultivated by man, it is considered to be the oldest tree with great genetic diversity (Popenoe, 1973). Date palm is an important fruit crop in Egypt where the total annual production of date fruits is about 1,730,000 tonnes (FAO Statistics, 2018). It is the most common fruit tree grown in semiarid and arid regions it plays an important role in the protection of interplant cropping system and the stabilization of the ecological system (Hasnaou et al., 2011). For this reason date palm is considered one of the suitable trees which could be cultivated in the new reclaimed desert regions. In Egypt, date palm is one of the most important fruits and widely distributed in different districts, where they are harvested and market at three stages of their development. The Arabic names for the various stages of development of dates are the terms used universally. After pollination, date fruits initially have a slow growth period essentially due to cell division up to the end of the six weeks from pollination. Thereafter fruits enter into the rapid phase of growth which is termed the "Kimiri" stage when fruits are young and green in color (16 weeks from pollination). Fruits then begin to change color and reach maximum weight and size at the "Khalal" (also called "Bisr") stage (20 weeks from pollination); this is considered as the 
maturi- ty stage. Fruits enter the ripening or "Rutab" stage ( 22 weeks from pollination) when the fruit begins to soften, lose moisture content and astringency, and starts acquiring a dark and less attractive color (Kassem, 2012). Finally, fruits con- tinue to lose their fresh weight and reach the lowest value at the "Tamr" stage (23 weeks from pollination) which may be considered as the senescence stage (Hobani et al., 2003; Taain, 2013). Soft cultivars are harvested and used at the "Khalal" and "Rutab" stages, but semi-dry and dry cultivars are harvested and used at the "Tamr" stage (Riad, 1993). Among all Egyptian governorates, New Valley ranked the fourth position after Sharkia, Behaira and Aswan according to acreage and the number of female palms. It is well known fact that morphological plasticity is a major weak point in assessment of phenotypic diversity. However, the study on inheritance of agronomic traits of fruit trees (citrus) is known to be controlled by multiple genes, which can be authenticated only through morphological characterization (Liu and Deng, 2007). The correct identification palms based on physiological and morphological markers is usually not possible until fruits are produced. Moreover, the characterization and evaluation of genetic diversity based on large set of phenotypic data is often difficult to assess due to environmental influences (Sedra et al., 1998). Molecular markers based on DNA sequence proved to be an ideal means for the identification and estimation of relatedness among genotypes of different origin. Different markers based on DNA sequences have been developed in the previous years for DNA fingerprinting and genome mapping (Naz et al., 2014). DNA-based molecular markers have been employed to provide reliable useful information on the genetic diversity, relationship between cultivars, DNA fingerprinting, and pedigree analysis (Ayesh, 2017; Haider, 2017; Purayil et al., 2018). Recently, inter simple sequence repeats (ISSR) markers have been emerged as an alternative system with reliability and advantages of microsatellites (SSRs) (Cregan, 1992). The ISSR strategy was therefore performed to access the DNA diversity among crop genotypes (Zehdi et al., 2004). ISSR markers are also believed to be simple, rapid, inexpensive and highly reproducible due to their primer length and to the high stringency achieved to be one of the most efficient techniques that can rapidly reveal high polymorphism and determine genetic diversity in date palm (Zehdi et al., 2004). Determination of genetic relationships among date palm cultivars is of major importance for characterization of date palm germplasm, breeding programs, and conservation purposes. The present study signifies the applicability of ISSR marker system in detecting genetic diversity of date palm cultivars. This may facilitate the conservation and improvement of date palm cultivars in the future. The aim of the study is the analysis of the genetic diversity among a set of Egyptian date palm varieties.

The aim of this work was elucidating the differences on growth, fruiting aspects and identify the genetic diversity between five date palm cultivars namely "Bartamoda", "Sakoty", "Soltany", "Sewy" and "Barhy".

\section{Materials and methods}

The present study was carried out during the two successive seasons of 2016 and 2017 on evaluated vegetative growth, physical and chemical fruit properties as well as genetic diversity analysis of some date palm cultivars grown at private orchards of ElDakhla Oasis, New Valley governorate, Egypt (which lies between $22^{\circ}$ and $31^{\circ}$ North latitudes and between $25^{\circ}$ and $35^{\circ}$ East longitudes. Its climate (comprising a mild and wet winter from November to April and a hot and dry summer from May to October) is suitable for the production of many field and horticultural crops (Directorate of 
Intelligence, 2011).). These cultivars are classified and nominated according to their moisture content in to three groups as follows: a) dry date palm cultivars (Bartamoda, Sakoty and Soltany) b) semidry date palm cultivars (Sewy) c) soft date palm cultivars (Barhy). Three trees were chosen for each cultivar of about 23-25 years old, grown in sandy loam soil. The palms were similar in vigor and received the same orchard management. The inflorescences of the trees under this study were manually pollinated by one source of pollen. At first week of October vegetative characteristics of chosen trees were measured in both seasons. Leave length $(\mathrm{m})$, umber of leaflet, number of spines, leaflet area $\left(\mathrm{cm}^{2}\right)$, leave zone $(\mathrm{m})$, spine length $(\mathrm{cm})$, leaflet length $(\mathrm{cm})$ and leaflet width $(\mathrm{cm})$ were measured. Total yield was determined at harvest, each spathe was weighed separately using weighing balance and was expressed in kilogram $(\mathrm{kg})$. For fruit properties fifty fruits were randomly taken from each palm. Physical properties of fruits included fruit and seed weight as well as flesh weight, percentage of flesh, fruit length, seed length and fruit dimensions. The chemical constituents included: Moisture content was determined in about $50 \mathrm{~g}$ of chopped flesh sample which was taken and dried in draft oven at $70{ }^{\circ} \mathrm{C}$ until a constant weight was obtained, soluble solids content (SSC) was determined by using a hand refractometer according to Chen and Mellenthin (1981). Titratable acidity percentage in the flesh expressed as percentage by titration against $\mathrm{NaOH}(0.1 \mathrm{~N})$ using phenolphethaline as an indicator as described by A. O.A.C. (1985). Total and reducing sugars concentration were determined according to Lan and Eynon method as described by the A.O.A.C. (1985).

\section{Molecular analysis}

\section{DNA extraction}

Fresh leaves of date palm were collected separately from different strains and cultivar. Then DNA extraction was performed as described by Dellaporta et al. (1983). About $0.1 \mathrm{~g}$ (fresh weight) of plant tissues was ground to fine powder in liquid $\mathrm{N}_{2}$ using mortar and pestle. Before the tissue thawed, $1 \mathrm{ml}$ extraction buffer $(100 \mathrm{mM}$ Tris- $\mathrm{HCl}$ $\mathrm{pH} 8.0,50 \mathrm{mM}$ EDTA and $0.5 \mathrm{M} \mathrm{NaCl}$ ) and $0.2 \mathrm{ml} \mathrm{20 \%}$ SDS were added. The mixture was incubated at $65^{\circ} \mathrm{C}$ in water bath for 20 minutes. Then $1 \mathrm{ml}$ of phenol, chloroform and isoamyl alcohol (25:24: 1) was added. Centrifugation was performed at 10,000 rpm for $10 \mathrm{~min}$. The supernatants of each sample were transferred separately to new tubes, and then $1 \mathrm{ml}$ of chloroform and isoamyl alcohol (24:1) was added. Centrifugation was performed at 10,000 rpm for 10 minutes. The supernatants of each sample were transferred separately to a new tube, then $1 \mathrm{ml}$ of isopropanol was added and then kept overnight in a freezer. Centrifugation was performed at $10,000 \mathrm{rpm}$ for $10 \mathrm{~min}$. The resulted pellets containing DNA were re-suspended in $1 \mathrm{ml}$ ethanol. Centrifugation was performed at 10,000 rpm for $2 \mathrm{~min}$. The DNA pellets were re-suspended in $200 \mathrm{TE}$ buffer (10 mM Tris-HCl pH 8.0 and $1 \mathrm{mM}$ EDTA). DNA purity and quantity was determined by UV -spectrophotometer and gel electrophoresis.

\section{ISSR-PCR analysis}

ISSR-PCR reactions were conducted using five primers. Amplification was conducted in $25 \mu \mathrm{l}$ reaction volume containing the following reagents: $2.5 \mu 1$ of dNTPs $(2.5 \mathrm{mM}), 2.5 \mu 1 \mathrm{Mgcl} 2(2.5 \mathrm{mM})$, and $2.5 \mu \mathrm{l}$ of $10 \times$ buffer, $3.0 \mu 1$ of primer $(10 \mathrm{pmol})$, $3.0 \mu \mathrm{l}$ of template DNA $(25 \mathrm{ng} / \mu \mathrm{l}), 1 \mu \mathrm{l}$ of Taq polymerase $(1 \mathrm{U} / \mu \mathrm{l})$ and $12.5 \mu \mathrm{l}$ of sterile dd $\mathrm{H}_{2} \mathrm{O}$. the PCRs were programmed for one cycle at $94{ }^{\circ} \mathrm{C}$ for $4 \mathrm{~min}$ followed 
by 45 cycles of $1 \mathrm{~min}$ at $94{ }^{\circ} \mathrm{C}, 1 \mathrm{~min}$ at $40-48{ }^{\circ} \mathrm{C}$ (according to the primer), $2 \mathrm{~min}$ at $72{ }^{\circ} \mathrm{C}$, then the reaction was finally stored at $72{ }^{\circ} \mathrm{C}$ for $10 \mathrm{~min}$. The PCR products were separated on a $1.5 \%$ agarose gels and fragments sizes were estimated with the $100 \mathrm{bp}$ ladder DNA marker (Fermentas.com).

\section{Inter simple sequence repeat (ISSR-PCR) procedure}

PCR reactions were conducted using 5 arbitrary 10-mer primers. Their names and sequences are shown in Table 1.

Table 1. List of the primer names and their nucleotide sequences used in the study for ISSR procedure.

\begin{tabular}{c|c|c|c}
\hline No. & Name & Sequence & Annealing temp. \\
\hline 1 & 14A & 5' CTC TCT CTC TCT CTC TTG 3' & 40 \\
2 & 44B & 5' CTC TCT CTC TCT CTC TGC 3' & 40 \\
3 & HB-09 & 5' ACC CGC AAGG 3' & 48 \\
4 & HB-12 & 5' CACCACCACGC 3' & 45 \\
5 & HB-15 & 5' GTG GTG GTG GC 3' & 48 \\
\hline
\end{tabular}

\section{Statistical analysis}

The experiment was set as randomized complete block design with three replicates (each palm as a replicate) per treatment (cultivar) according to Little and Hills (1972) and analyzed by the standard methods according to Snedecor and Cochran (1980). The new L.S.D. test was used for comparison between means. The DNA bands generated by each primer were counted and their molecular sizes were compared with those of the DNA markers. The bands scored from DNA profiles generated by each primer were pooled together. Then the presence or absence of each DNA band was treated as calculate genetic similarity and to construct dendrogram tree among the studied date palm seedling strains and Bartamoda cultivars. Calculation was achieved using Dice Similarity Coefficients (Dice, 1945) as implemented in the computer program SPSS-10.

\section{Results and discussion}

\section{Vegetative measurements}

Data presented in Table 2 showed the vegetative measurements of five date palm cultivars. Results showed that Soltany cv. gave the highest values of leaf length (5.39 and $5.53 \mathrm{~m}$ ) and number of spins (54.2 and 53.66).

While Barhy cv., had the highest value of leaflet area $\left(161.59\right.$ and $\left.176.70 \mathrm{~cm}^{2}\right)$. Also, results indicated that Sewy cv. recorded the highest of leaflet zone/leave (3.37 and $.366 \mathrm{~m}$ ). Sakoty cv., gave the highest value of number of leaflet (212 and 214). On other hand, Bartamoda cv., gave the lowest value of leaf length $(3.57 \mathrm{~m})$, number of leaflet (173.2) and number of spines (25.2) in the first season and the number of leaflet (179.66) and leaflet zone/leave $(2.81 \mathrm{~m})$ in the second season. These results are in agreement with Abdalla (1979) found that with Iraq and Egyptian date palm cultivars, i.e., Brahee, Hallawy, Sayer and Samany the number of spines per leaf and spine length were in the average of $15-29$ and $4-13 \mathrm{~cm}$, respectively. 
Table 2. Some morphological measurements of five date palm cultivars grown under New Valley condition during 2016 and 2017 seasons

\begin{tabular}{c|c|c|c|c|c|c|c|c|c|c}
\hline \multirow{2}{*}{ Strains } & \multicolumn{3}{|c|}{$\begin{array}{c}\text { Leaf length } \\
(\mathbf{m})\end{array}$} & \multicolumn{2}{c|}{ No-of leaflet } & \multicolumn{2}{c|}{ No-of spines } & \multicolumn{2}{c|}{ Leaflet area $\left(\mathbf{c m}^{\mathbf{2}}\right)$} & \multicolumn{2}{c}{$\begin{array}{c}\text { Leaflet } \\
\text { zone/leave (m) }\end{array}$} \\
\cline { 2 - 12 } & $\mathbf{2 0 1 6}$ & $\mathbf{2 0 1 7}$ & $\mathbf{2 0 1 6}$ & $\mathbf{2 0 1 7}$ & $\mathbf{2 0 1 6}$ & $\mathbf{2 0 1 7}$ & $\mathbf{2 0 1 6}$ & $\mathbf{2 0 1 7}$ & $\mathbf{2 0 1 6}$ & $\mathbf{2 0 1 7}$ \\
\hline Bartamoda cc & $3.57 \mathrm{~d}$ & $4.65 \mathrm{c}$ & $173.2 \mathrm{~d}$ & $179.66 \mathrm{~d}$ & $25.2 \mathrm{c}$ & $27.33 \mathrm{c}$ & $130.06 \mathrm{~b}$ & $126.52 \mathrm{bc}$ & $2.8 \mathrm{~b}$ & $2.81 \mathrm{~b}$ \\
Sakoty & $3.67 \mathrm{~d}$ & $3.68 \mathrm{c}$ & $212 \mathrm{a}$ & $214 \mathrm{a}$ & $25.6 \mathrm{c}$ & $25.33 \mathrm{c}$ & $98.31 \mathrm{c}$ & $96.85 \mathrm{c}$ & $2.92 \mathrm{~b}$ & $2.86 \mathrm{~b}$ \\
Soltany & $5.39 \mathrm{a}$ & $5.53 \mathrm{a}$ & $198.2 \mathrm{~b}$ & $200.66 \mathrm{~b}$ & $54.2 \mathrm{a}$ & $53.66 \mathrm{a}$ & $134.06 \mathrm{ab}$ & $124.06 \mathrm{bc}$ & $3.52 \mathrm{a}$ & $3.43 \mathrm{ab}$ \\
Sewy & $3.37 \mathrm{a}$ & $5.2 \mathrm{a}$ & $187 \mathrm{c}$ & $197.33 \mathrm{~b}$ & $27.2 \mathrm{c}$ & $28.66 \mathrm{c}$ & $132.30 \mathrm{ab}$ & $149.53 \mathrm{ab}$ & $3.37 \mathrm{a}$ & $3.66 \mathrm{a}$ \\
Barhy & $4.37 \mathrm{c}$ & $4.38 \mathrm{~b}$ & $186.8 \mathrm{c}$ & $190 \mathrm{c}$ & $33.8 \mathrm{~b}$ & $34.33 \mathrm{~b}$ & $161.59 \mathrm{a}$ & $176.70 \mathrm{a}$ & $3.02 \mathrm{~b}$ & $3.17 \mathrm{ab}$ \\
\hline
\end{tabular}

Values with the same letter in the same column are not significant at $(\mathrm{P} \geq 0.05)$

\section{Yield parameters, number of bunches and fruit physical characteristics}

It is clear from obtained data in Tables 3 and 4 and Fig. 1 showed that Barhy cv., had the highest values in most studied fruit physical characteristics as compared to other studied cultivars. It, was gave the highest fruit weight (15.23 and $16.33 \mathrm{~g})$, flesh weight (13.89 and $14.99 \mathrm{~g}$ ) and flesh percentage (91.11 and 91.76\%). While, Sewy cv. gave the highest seed weight (1.71 and $1.80 \mathrm{~g})$.

Table 3. Yield parameters, number of bunches and fruit physical characteristics of five date palm cultivars grown under New Valley condition during first season (2016)

\begin{tabular}{c|c|c|c|c|c|c|c|c|c}
\hline Strains & $\begin{array}{c}\text { Fruit } \\
\text { weight } \\
(\mathbf{g})\end{array}$ & $\begin{array}{c}\text { Flesh } \\
\text { weight } \\
(\mathbf{g})\end{array}$ & $\begin{array}{c}\text { Seed } \\
\text { weight } \\
(\mathbf{g})\end{array}$ & $\begin{array}{c}\text { Seed } \\
\text { length } \\
(\mathbf{c m})\end{array}$ & $\begin{array}{c}\text { Fruit } \\
\text { length } \\
(\mathbf{c m})\end{array}$ & $\begin{array}{c}\text { Fruit } \\
\text { diameter } \\
(\mathbf{c m})\end{array}$ & $\begin{array}{c}\text { Flesh } \\
\mathbf{\%}\end{array}$ & $\begin{array}{c}\text { No- } \\
\text { bunch/ } \\
\text { palm }\end{array}$ & $\begin{array}{c}\text { Yield/ } \\
\text { palm }\end{array}$ \\
\hline Bartamoda cv & $6.17 \mathrm{~d}$ & $5.16 \mathrm{~d}$ & $1.00 \mathrm{c}$ & $2.3 \mathrm{~b}$ & $4.38 \mathrm{~b}$ & $2.04 \mathrm{c}$ & $83.77 \mathrm{c}$ & $10 \mathrm{~cd}$ & $89 \mathrm{~cd}$ \\
Sakoty & $8.34 \mathrm{c}$ & $7.42 \mathrm{c}$ & $0.91 \mathrm{c}$ & $2.74 \mathrm{a}$ & $5.00 \mathrm{a}$ & $1.98 \mathrm{c}$ & $88.98 \mathrm{ab}$ & $8.8 \mathrm{~d}$ & $80.5 \mathrm{~d}$ \\
Soltany & $11.16 \mathrm{~b}$ & $9.52 \mathrm{~b}$ & $1.64 \mathrm{a}$ & $2.46 \mathrm{ab}$ & $3.36 \mathrm{e}$ & $2.00 \mathrm{c}$ & $85.16 \mathrm{c}$ & $12.2 \mathrm{bc}$ & $98.16 \mathrm{c}$ \\
Sewy & $14.70 \mathrm{a}$ & $12.98 \mathrm{a}$ & $1.71 \mathrm{a}$ & $2.4 \mathrm{~b}$ & $4.18 \mathrm{c}$ & $2.58 \mathrm{~b}$ & $88.28 \mathrm{~b}$ & $13.8 \mathrm{~b}$ & $132.2 \mathrm{~b}$ \\
Barhy & $15.23 \mathrm{a}$ & $13.89 \mathrm{a}$ & $1.34 \mathrm{~b}$ & $1.8 \mathrm{c}$ & $3.62 \mathrm{~d}$ & $3.12 \mathrm{a}$ & $91.11 \mathrm{a}$ & $18.8 \mathrm{a}$ & $195.4 \mathrm{a}$ \\
\hline
\end{tabular}

Values with the same letter in the same column are not significant at $(\mathrm{P} \geq 0.05)$

On other hand, Sakoty cv. gave the lowest value of fruit diameter $(1.98$ and $1.96 \mathrm{~cm})$ and seed weight $(0.91$ and $0.91 \mathrm{~g})$. Also, Bartamoda cv., recorded the lowest value of flesh percentage (83.77 and $82.63 \%$ ).

Table 4. Yield parameters, number of bunches and fruit physical characteristics of five date palm cultivars grown under New Valley condition during second season (2016)

\begin{tabular}{c|c|c|c|c|c|c|c|c|c}
\hline Strains & $\begin{array}{c}\text { Fruit } \\
\text { weight } \\
(\mathbf{g})\end{array}$ & $\begin{array}{c}\text { Flesh } \\
\text { weight } \\
(\mathbf{g})\end{array}$ & $\begin{array}{c}\text { Seed } \\
\text { weight } \\
(\mathbf{g})\end{array}$ & $\begin{array}{c}\text { Seed } \\
\text { length } \\
(\mathbf{c m})\end{array}$ & $\begin{array}{c}\text { Fruit } \\
\text { length } \\
(\mathbf{c m})\end{array}$ & $\begin{array}{c}\text { Fruit } \\
\text { diameter } \\
(\mathbf{c m})\end{array}$ & $\begin{array}{c}\text { Flesh } \\
\mathbf{\%}\end{array}$ & $\begin{array}{c}\text { No- } \\
\text { bunch/ } \\
\text { palm }\end{array}$ & $\begin{array}{c}\text { Yield/ } \\
\text { palm }\end{array}$ \\
\hline Bartamoda cv & $6.19 \mathrm{~d}$ & $5.11 \mathrm{~d}$ & $1.07 \mathrm{~cd}$ & $3.69 \mathrm{a}$ & $4.43 \mathrm{~b}$ & $2.1 \mathrm{c}$ & $82.63 \mathrm{c}$ & $9.66 \mathrm{c}$ & $91.0 \mathrm{~cd}$ \\
Sakoty & $8.45 \mathrm{c}$ & $7.54 \mathrm{c}$ & $0.91 \mathrm{~d}$ & $2.83 \mathrm{a}$ & $5.06 \mathrm{a}$ & $1.96 \mathrm{~d}$ & $89.17 \mathrm{ab}$ & $9.0 \mathrm{c}$ & $81.0 \mathrm{~d}$ \\
Soltany & $11.76 \mathrm{~b}$ & $10.16 \mathrm{~b}$ & $1.6 \mathrm{ab}$ & $2.4 \mathrm{a}$ & $3.46 \mathrm{e}$ & $2.03 \mathrm{~cd}$ & $86.29 \mathrm{~b}$ & $12.33 \mathrm{~b}$ & $94.61 \mathrm{e}$ \\
Sewy & $16.03 \mathrm{a}$ & $14.23 \mathrm{a}$ & $1.80 \mathrm{a}$ & $2.5 \mathrm{a}$ & $4.2 \mathrm{c}$ & $3.63 \mathrm{~b}$ & $88.72 \mathrm{ab}$ & $13.66 \mathrm{~b}$ & $124.06 \mathrm{~b}$ \\
Barhy & $16.33 \mathrm{a}$ & $14.99 \mathrm{a}$ & $1.34 \mathrm{bc}$ & $1.8 \mathrm{a}$ & $3.66 \mathrm{~d}$ & $3.2 \mathrm{a}$ & $91.76 \mathrm{a}$ & $18.66 \mathrm{a}$ & $197.21 \mathrm{a}$ \\
\hline
\end{tabular}

Values with the same letter in the same column are not significant at $(\mathrm{P} \geq 0.05)$ 

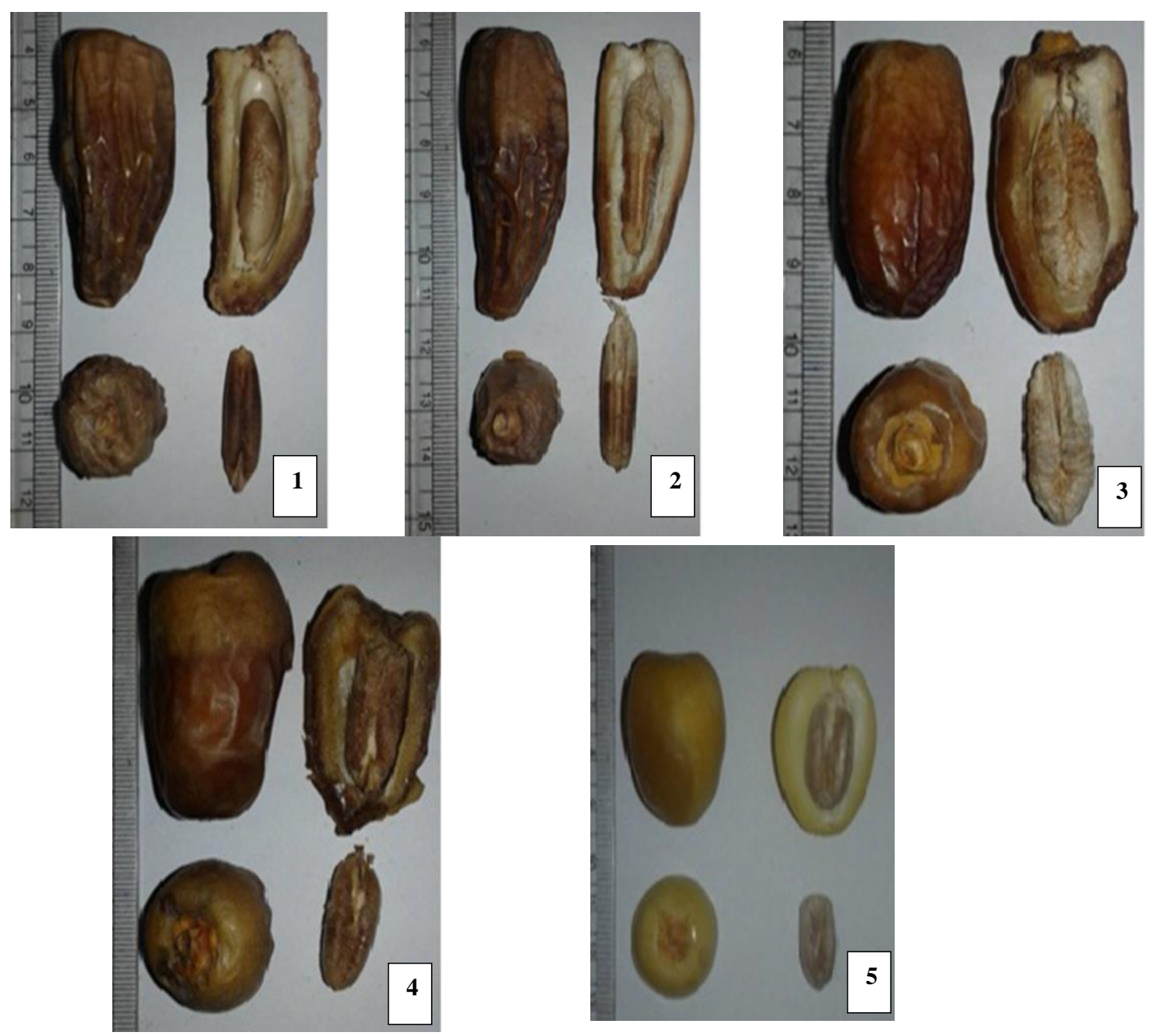

Figure 1. The fruit of five date palm cultivars. 1 Bartamoda, 2 Sakoty, 3 Soltany, 4 Sewy, and 5 Barhy

Regarding number of bunches and yield/palm, Barhy cv., had the highest number of bunches (18.8 and 18.66) and yield/palm (195.4 and 197.21 kg) followed by Sewy cv. in both seasons. On other hand, Sakoty cv. gave the lowest number of bunches ( 9 and $8.8)$ and yield/ palm $(80.5$ and $81 \mathrm{~kg})$. These results are in harmony with present results those obtained by Abo-Rekab et al. (2014), Idris et al. (2014), Mortazavi et al. (2015), Nasir et al. (2015), Omaima, et al. (2015), Qadri et al. (2016), Abd-El Hamed, et al. (2017). Who found that Sakoti gave the lowest seed weight in both seasons (0.961 and $0.985 \mathrm{~g}$, respectively) (Abo Rekab et al., 2010). These data are in agreement with ElMerghany et al. (2013) they found that Barhy cv. gave the highest yield/palm in the second season.

\section{Chemical properties}

Data presented in Table 5 showed the chemical properties of five date palm cultivars. Results showed that Sewy cv. gave the highest value of reducing and total sugar (65.41 and 64.88) and (74.64 and 74.46) respectively, while Barhy cv. recorded the highest moisture \% (31.56 and $31.23 \%$ ) as compared to other date palm cultivars. 
Table 5. Fruit chemical properties of five date palm cultivars grown under New Valley condition during 2015 and season (2016)

\begin{tabular}{c|c|c|c|c|c|c|c|c|c|c|c|c}
\hline Cultivars & \multicolumn{2}{|c|}{ Moisture \% } & \multicolumn{2}{|c|}{ T.S.S } & \multicolumn{2}{c|}{ Acidity \% } & \multicolumn{2}{c|}{ Reducing sugars } & \multicolumn{2}{c}{$\begin{array}{c}\text { Non-reducing } \\
\text { sugar \% }\end{array}$} & \multicolumn{2}{c}{ Total sugar \% } \\
\hline Seasons & $\mathbf{2 0 1 6}$ & $\mathbf{2 0 1 7}$ & $\mathbf{2 0 1 6}$ & $\mathbf{2 0 1 7}$ & $\mathbf{2 0 1 6}$ & $\mathbf{2 0 1 7}$ & $\mathbf{2 0 1 6}$ & $\mathbf{2 0 1 7}$ & $\mathbf{2 0 1 6}$ & $\mathbf{2 0 1 7}$ & $\mathbf{2 0 1 6}$ & $\mathbf{2 0 1 7}$ \\
\hline Bartamoda & $14.26 \mathrm{~d}$ & $14.61 \mathrm{~d}$ & $78.76 \mathrm{ab}$ & $79.87 \mathrm{a}$ & $0.136 \mathrm{~d}$ & $0.137 \mathrm{c}$ & $7.33 \mathrm{~d}$ & $7.48 \mathrm{e}$ & $63.22 \mathrm{a}$ & $63.23 \mathrm{a}$ & $70.56 \mathrm{bc}$ & $71.04 \mathrm{~b}$ \\
Sakoty & $12.93 \mathrm{e}$ & $12.96 \mathrm{e}$ & $78.42 \mathrm{~b}$ & $78.31 \mathrm{~b}$ & $0.199 \mathrm{~b}$ & $0.200 \mathrm{~b}$ & $10.20 \mathrm{c}$ & $10.06 \mathrm{~d}$ & $60.12 \mathrm{~b}$ & $61 \mathrm{~b}$ & $71.06 \mathrm{~b}$ & $71.06 \mathrm{~b}$ \\
Soltany & $17.4 \mathrm{c}$ & $17.36 \mathrm{c}$ & $79.58 \mathrm{a}$ & $78.48 \mathrm{~b}$ & $0.223 \mathrm{a}$ & $0.223 \mathrm{a}$ & $11.4 \mathrm{c}$ & $11.7 \mathrm{c}$ & $58.46 \mathrm{c}$ & $58.4 \mathrm{c}$ & $69.86 \mathrm{c}$ & $70.00 \mathrm{~b}$ \\
Sewy & $23.96 \mathrm{~b}$ & $23.87 \mathrm{~b}$ & $78.2 \mathrm{~b}$ & $77.85 \mathrm{~b}$ & $0.037 \mathrm{e}$ & $0.046 \mathrm{~d}$ & $65.41 \mathrm{a}$ & $64.88 \mathrm{a}$ & $9.23 \mathrm{e}$ & $9.58 \mathrm{e}$ & $74.64 \mathrm{a}$ & $74.46 \mathrm{a}$ \\
Barhy & $31.56 \mathrm{a}$ & $31.23 \mathrm{a}$ & $57.83 \mathrm{c}$ & $58.16 \mathrm{c}$ & $0.187 \mathrm{c}$ & $0.188 \mathrm{~b}$ & $37.66 \mathrm{~b}$ & $38.00 \mathrm{~b}$ & $14.00 \mathrm{~d}$ & $13.66 \mathrm{~d}$ & $51.66 \mathrm{~d}$ & $51.66 \mathrm{c}$ \\
\hline
\end{tabular}

Values with the same letter in the same colum are not significant at $(\mathrm{P} \geq 0.05)$

Also, Soltany cv. had the highest of acidity (0.223 and $0.223 \%)$. On other hand, Bartamoda cv. gave the lowest value of reducing sugar (7.33 and 7.48\%). While, Sakoty cv. had the lowest of moisture \% (12.93 and 12.96\%). Also, Barhy cv. recorded the lowest of total sugars (51.66 and 51.66). These results are in agreement with many researchers such as Gadalla et al. (2013), Idris et al. (2014), Mortazavi et al. (2015), Nasir et al. (2015), El-Salhy et al. (2016), Qadri et al. (2016), Abd-El Hamed et al. (2017), who found that Barhy at khalal stage gave the lowest total sugars percentage (51 and 50\%) in both season. Youssef et al. (1998) found that total sugars concentration in fruits of eight date palm cultivars (from different areas of Upper Egypt) were ranged from 73.65 to $81.77 \%$ for dry cultivars.

\section{Identification of ISSR-PCR markers}

To determine the genetic relationships among the 5 date palm cultivars, ISSR profile resulting from using 5 tested primers, i.e. 14A, 44B, HB- 09, HB-12 and HB-15 were illustrated in Table 6 and Figure 2.

Table 6. The ISSR analysis products produced by the five primers investigated of ten date palm seedlings strains as well as Bartamoda cultivar. (1 means presence and 0 means absence)

\begin{tabular}{|c|c|c|c|c|c|c|}
\hline \multirow{2}{*}{ Band no. } & \multirow{2}{*}{ M.W bp } & Sewy & Soltany & Bartamoda & Sakoty & Barhy \\
\hline & & \multicolumn{5}{|c|}{$14 \mathrm{~A}$} \\
\hline 1 & 565 & 1 & 1 & 1 & 1 & 1 \\
\hline 2 & 435 & 0 & 0 & 0 & 0 & 1 \\
\hline 3 & 370 & 1 & 1 & 0 & 1 & 1 \\
\hline 4 & 315 & 1 & 1 & 0 & 0 & 0 \\
\hline 5 & 265 & 0 & 0 & 1 & 0 & 0 \\
\hline \multicolumn{2}{|c|}{ Total } & 3 & 3 & 2 & 2 & 3 \\
\hline Band no. & M.W bp & \multicolumn{5}{|c|}{ 44B } \\
\hline 1 & 825 & 0 & 0 & 0 & 0 & 1 \\
\hline 2 & 690 & 0 & 1 & 0 & 0 & 0 \\
\hline 3 & 510 & 0 & 0 & 0 & 1 & 0 \\
\hline 4 & 425 & 0 & 0 & 0 & 0 & 0 \\
\hline 5 & 355 & 1 & 1 & 0 & 1 & 1 \\
\hline 6 & 280 & 1 & 1 & 1 & 1 & 1 \\
\hline 7 & 225 & 1 & 1 & 1 & 1 & 1 \\
\hline 8 & 190 & 1 & 1 & 1 & 1 & 1 \\
\hline \multicolumn{2}{|c|}{ Total } & 4 & 5 & 3 & 5 & 5 \\
\hline
\end{tabular}




\begin{tabular}{|c|c|c|c|c|c|c|}
\hline Band no. & M.W bp & \multicolumn{5}{|c|}{ HB-09 } \\
\hline 1 & 985 & 1 & 0 & 1 & 0 & 0 \\
\hline 2 & 880 & 0 & 1 & 0 & 1 & 1 \\
\hline 3 & 860 & 0 & 0 & 0 & 0 & 0 \\
\hline 4 & 735 & 1 & 0 & 1 & 0 & 0 \\
\hline 5 & 615 & 0 & 1 & 0 & 1 & 1 \\
\hline 6 & 520 & 0 & 0 & 0 & 0 & 0 \\
\hline 7 & 450 & 1 & 1 & 0 & 0 & 0 \\
\hline 8 & 415 & 1 & 1 & 1 & 1 & 1 \\
\hline 9 & 355 & 1 & 1 & 1 & 1 & 1 \\
\hline 10 & 315 & 1 & 1 & 1 & 0 & 1 \\
\hline 11 & 250 & 1 & 1 & 1 & 1 & 1 \\
\hline 12 & 215 & 1 & 1 & 1 & 1 & 1 \\
\hline 13 & 180 & 1 & 1 & 1 & 1 & 1 \\
\hline \multicolumn{2}{|c|}{ Total } & 9 & 9 & 8 & 7 & 8 \\
\hline Band no. & M.W bp & \multicolumn{5}{|c|}{ HB-12 } \\
\hline 1 & 985 & 1 & 0 & 1 & 1 & 1 \\
\hline 2 & 880 & 0 & 0 & 1 & 1 & 1 \\
\hline 3 & 860 & 1 & 0 & 0 & 0 & 0 \\
\hline 4 & 735 & 1 & 0 & 1 & 1 & 1 \\
\hline 5 & 615 & 1 & 0 & 1 & 1 & 1 \\
\hline 6 & 520 & 1 & 0 & 1 & 1 & 1 \\
\hline 7 & 450 & 1 & 1 & 1 & 1 & 1 \\
\hline 8 & 415 & 1 & 0 & 1 & 1 & 1 \\
\hline 9 & 355 & 1 & 0 & 1 & 1 & 1 \\
\hline 10 & 315 & 0 & 1 & 1 & 0 & 0 \\
\hline \multicolumn{2}{|c|}{ Total } & 8 & 2 & 9 & 8 & 8 \\
\hline Band no. & M.W bp & \multicolumn{5}{|c|}{ HB-15 } \\
\hline 1 & 2075 & 0 & 0 & 0 & 0 & 0 \\
\hline 2 & 1600 & 1 & 1 & 0 & 1 & 1 \\
\hline 3 & 1370 & 1 & 1 & 0 & 1 & 1 \\
\hline 4 & 1355 & 1 & 1 & 0 & 0 & 0 \\
\hline 5 & 1150 & 1 & 1 & 1 & 1 & 1 \\
\hline 6 & 1115 & 1 & 1 & 0 & 1 & 1 \\
\hline 7 & 910 & 0 & 0 & 0 & 0 & 0 \\
\hline 8 & 825 & 1 & 1 & 0 & 0 & 0 \\
\hline 9 & 800 & 1 & 1 & 0 & 1 & 1 \\
\hline 10 & 575 & 1 & 1 & 1 & 1 & 1 \\
\hline 11 & 510 & 1 & 1 & 1 & 1 & 1 \\
\hline 12 & 415 & 1 & 1 & 1 & 1 & 1 \\
\hline 13 & 310 & 1 & 1 & 0 & 1 & 1 \\
\hline 14 & 275 & 1 & 1 & 1 & 1 & 1 \\
\hline 15 & 220 & 1 & 1 & 1 & 0 & 0 \\
\hline 16 & 150 & 1 & 1 & 1 & 1 & 1 \\
\hline \multicolumn{2}{|c|}{ Total } & 14 & 14 & 7 & 9 & 9 \\
\hline
\end{tabular}

A total number of 52 ISSR bands were obtained of these 31 bands were polymorphic $(59.61 \%)$ and 21 were monomorphic $(40.38 \%)$ both primer HB-12 and 14A exhibited high polymorphism percentage (90 and $80 \%$ ), respectively. On the other hand, primer HB-09 exhibited low polymorphism (46.15\%). Primer 14A showed three specific fragments two of them was positive markers with molecular size $435 \mathrm{bp}$ and $265 \mathrm{bp}$ for 
Barhy and Bartamoda cultivars and the other specific fragments was negative marker with molecular size $370 \mathrm{p}$ for Bartamoda cultivar. Primer 44B showed four specific fragments, three of them was positive markers with molecular size 825, 690 and $510 \mathrm{bp}$ for Barhy, Soltany and Sakoty, respectively, and the other specific fragment was negative markers for Bartamoda cultivar. Primer HB-09 showed specific fragment (315 bp) as negative marker for Sakoty cultivar. Primer HB-12 Showed specific fragment, one of them was positive marker with molecular size 860 bp for Sewy cultivar and the other specific fragments (six markers) was negative marker for Soltany cultivar. Primer HB-15 showed specific fragment, each these fragments were negative markers for Bartamoda cultivar (Table 7 and Fig. 2).

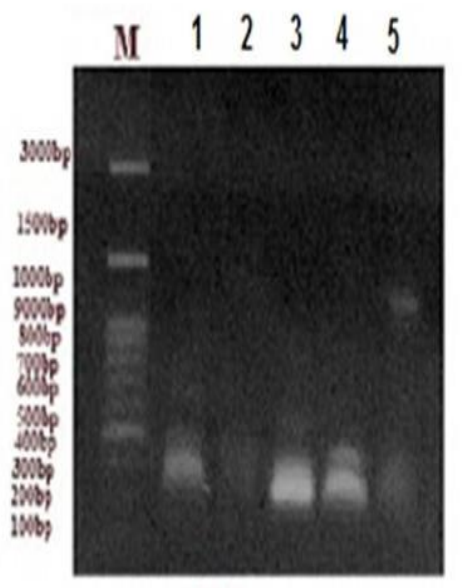

$14 \mathrm{~A}$

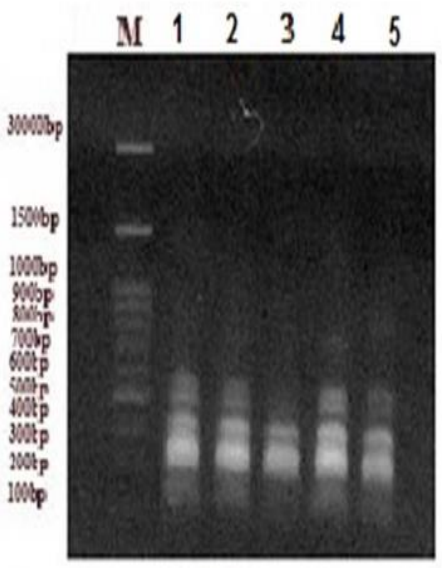

$1 / \mathrm{B}$

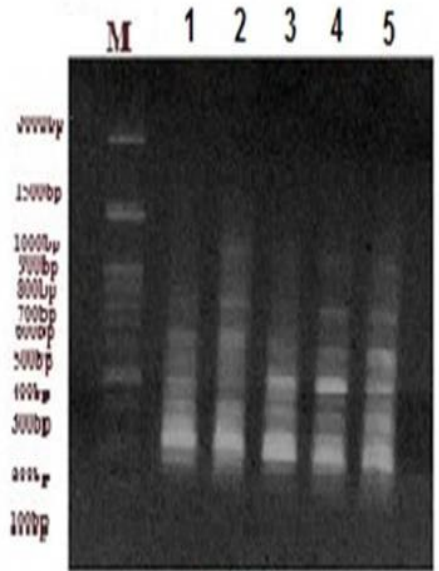

$\mathrm{HB}-\mathrm{OP}$

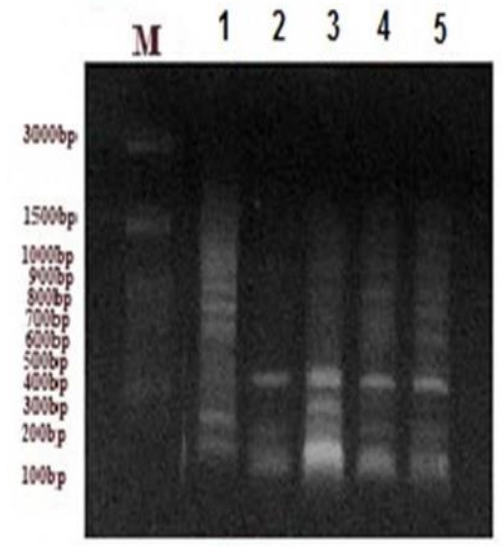

HB-12

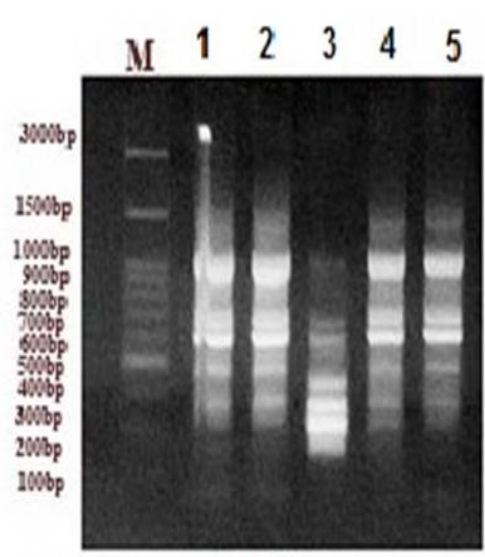

HB-15

Figure 2. ISSR products generated with primers $14 \mathrm{~A}, 44 \mathrm{~B}, \mathrm{HB}-09, \mathrm{HB}-12$ and $\mathrm{HB}-15$ in five date palm cultivars cultivar. (1: Sewy, 2: Soltany, 3: Bartamoda, 4: Sakoty, 5: Barhy)

A total number of 52 ISSR bands were obtained of these 31 bands were polymorphic (59.61\%) and 21 were monomorphic (40.38\%) both primer HB-12 and 14A exhibited high polymorphism percentage (90 and $80 \%$ ), respectively. On the other hand, primer 
HB-09 exhibited low polymorphism (46.15\%). Primer 14A showed three specific fragments two of them was positive markers with molecular size $435 \mathrm{bp}$ and $265 \mathrm{bp}$ for Barhy and Bartamoda cultivars and the other specific fragments was negative marker with molecular size $370 \mathrm{p}$ for Bartamoda cultivar. Primer 44B showed four specific fragments, three of them was positive markers with molecular size 825, 690 and $510 \mathrm{bp}$ for Barhy, Soltany and Sakoty, respectively, and the other specific fragment was negative markers for Bartamoda cultivar. Primer HB-09 showed specific fragment (315 bp) as negative marker for Sakoty cultivar. Primer HB-12 Showed specific fragment, one of them was positive marker with molecular size 860 bp for Sewy cultivar and the other specific fragments (six markers) was negative marker for Soltany cultivar. Primer HB-15 showed specific fragment, each these fragments were negative markers for Bartamoda cultivar (Table 6 and Fig. 2).

Table 7. Total number of bands, polymorphic band, monomorphic band, unique band and polymorphic $\%$

\begin{tabular}{c|c|c|c|c|c}
\hline $\begin{array}{c}\text { Primer } \\
\text { name }\end{array}$ & Total band & Polymorphic band & Monomorphic band & $\begin{array}{c}\text { Unique } \\
\text { band }\end{array}$ & Polymorphic \% \\
\hline 14A & 5 & 4 & 1 & 3 & 80 \\
44B & 8 & 4 & 4 & 4 & 50 \\
HB-09 & 13 & 6 & 7 & 1 & 46 \\
HB-12 & 10 & 9 & 1 & 7 & 90 \\
HB-15 & 16 & 8 & 8 & 5 & 50 \\
Total & 52 & 31 & 21 & 19 & - \\
\hline
\end{tabular}

\section{Genetic similarity and cluster analysis based on ISSR-markers}

The ISSR data were used to estimate the genetic similarity among five date palm cultivars by using UPGMA computer analysis as presented in Table 8.

Table 8. Genetic similarity matrices among the ten dry seedlings strains as well as Bartamoda cultivar accessions as compute according to Dice coefficient from ISSR

\begin{tabular}{c|c|c|c|c}
\hline Similarity & Sewy & Soltany & Bartamoda & Sakoty \\
\hline Soltany & 0.81 & 1.00 & & \\
Bartamoda & 0.77 & 0.61 & 1.00 & \\
Sakoty & 0.84 & 0.78 & 0.76 & 1.00 \\
Barhy & 0.84 & 0.78 & 0.77 & 1.00 \\
\hline
\end{tabular}

The highest similarity index (1.00) was recorded between Barhy and Sakoty date palm cultivar, while the lowest similarity index (0.61) was detected between Bartamoda and Soltany.

A dendrogram for the genetic relationship among the five date palm cultivars was drawn in Figure 3 which separated cultivars into two major cluster.

The first cluster contained the Bartamoda cultivar while the second cluster was divided into two subcluster where the first sub cluster included Soltany cultivar, while the second sub cluster consisted of two group, the first group included Sakoty and Bartamoda cultivars, whereas the second group included Sewy cultivar. The results of 
ISSR are in harmony with Sami et al. (2004). They concluded that the cultivar Siwi characterized by a unique positive marker (OPB05 $1700 \mathrm{bp}$ ). Zeinab et al. (2014) reported that using ISSR analysis which gave two specific DNA band with molecular size 640 and $160 \mathrm{bp}$ were absent (negative marker) for Shamia and Sakoty cultivar, respectively.

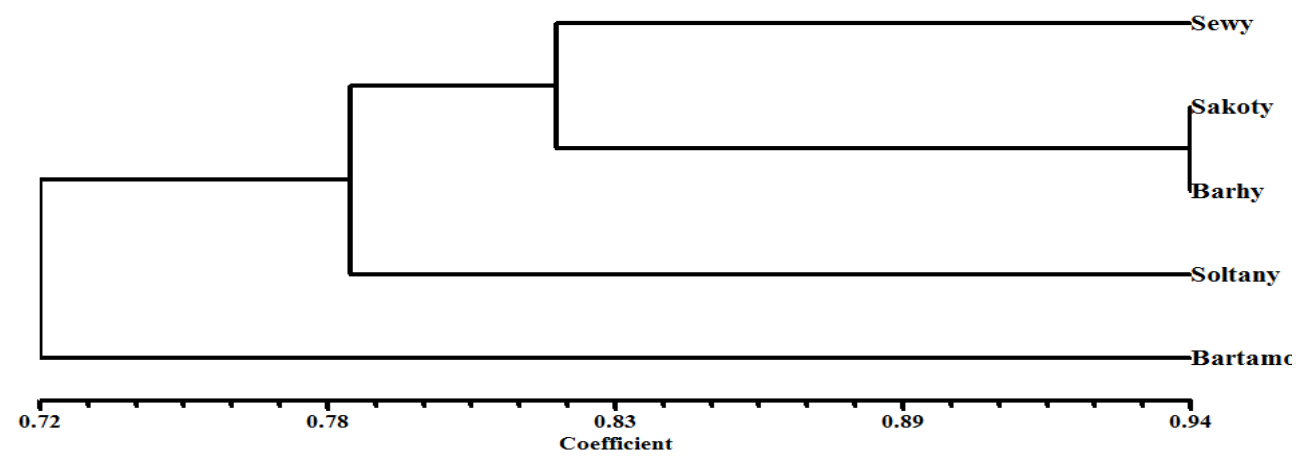

Figure 3. Dendrogram for the five date palm cultivars as accessions constructed from the ISSR data using unweighed pair-group arithmetic (UPGMA) and similarity matrices computed according to Dice coefficient

\section{Conclusion}

This morphological variation showed that the date palm varieties accessions under study were phenotypically different individuals. The results indicated the existence of diverse accessions in date palm germplasm in spite of similar morphological characters present in genotypes.

Thus, the SSR markers are effective to identify diversity or closeness in genotypes which may contribute to fasten the breeding programs and help in date palm crop improvement.

\section{REFERENCES}

[1] A.O.A.C. (1985): Methods of Analysis $14^{\text {th }}$ Ed. - Association of Official Agriculture Chemists, Washington. DC.

[2] Abdalla, M. Y. (1979): Studies on some soft date cultivar. - MSc Thesis, Fac. Agric., Zagazig Univ., Egypt.

[3] Abd-El Hamed, K., Darwesh Rasmia, S. S., Zayed, E. M. M. (2017): Evaluation physical and chemical characteristics of some seedlings date palm fruits (Maghal) in the North Delta Egypt. - International Journal of Advances in Agricultural Science and Technology 4(7): 13-32.

[4] Abo-Rekab, Z. A., Gadalla, E. G., Mohamed, S. Y. (2010): Morphological, physiological and molecular genetic evaluation of the most important Egyptian dry date palm. - J. Biol. Chem. Environ. Sci. 5(3): 23-47.

[5] Abo-Rekab, Z. A., Ghada, A., El-Kafrawy, T. M., Madboly, E. A. (2014): Physicochemical characters and molecular genetic evaluation of selected dry date palm seedling trees. - Middle East Journal of Applied Sciences 4(4): 931-941.

[6] Ayesh, B. M. (2017): Genotyping and Molecular Identification of Date Palm Cultivars Using Inter-Simple Sequence Repeat (ISSR) Markers. - In: Al-Khayri, J., Jain, S., Johnson, D. (eds.) Date Palm Biotechnology Protocols. Vol. II. Methods in Molecular Biology. Vol. 1638. Humana Press, New York. 
[7] Chen, P. M., Mellenthin, W. M. (1981): Effect of harvest date on ripening capacity and post-harvest life of d' Anjoupears'. - J. Amer. Soc. Hort. Sci. 106(1): 38-42.

[8] Cregan, B. (1992): Simple sequence repeats DNA length polymorphism. - Prole. 2: 1822.

[9] Dellaporta, S. L., Wood, J., Hicks, J. B. (1983): A plant DNA mini preparation. Version III. - Plant Mol. Biol. 1: 19-21.

[10] Dice, L. R. (1945): Measures of the amount of ecologic association between species. Ecology 26: 297-302.

[11] Directorate of Intelligence (2011): "CIA - World Fact-book". Information on the history, people, government, economy, geography, communications, transportation, military, and transnational issues for 267 world entities. - January 17 2013<https://www.cia. gov/library/publications/the-world-factbook/index. Html.

[12] El-Merghany, S., Zan El-Daen, E. M. A. (2013): Evaluation of some date palm cultivars grown under Toshky conditions'. - Plant Production, Mnsoura Univ. 4(8): 1207-1218.

[13] El-Salhy, A. M., Ibrahim, R. A., Gadalla, E. G., Khalil, H. K. H. (2016): Evaluation of some seeded dry date palm grown under Aswan climatic condition. - Assiut J. Agric. Sci. 47(4): 136-155.

[14] FAO Statistics (2018): http://www.fao.org/statistics/en. - Accessed on 23 July 2018.

[15] Gadalla, E. G., Abeer, H. I., Ahmed, E. F. S. (2013): Behavior of some Egyption dry cultivars and Barhee cv. Date palm produced from tissue culture under Shark Al- Oinat condition El -Wadi El -Gadid governorate. - J of Appl. Sci. 32(12).

[16] Haider, N. (2017): Determining Phylogenetic Relationships Among Date Palm Cultivars Using Random Amplified Polymorphic DNA (RAPD) and Inter-Simple Sequence Repeat (ISSR) Markers. - In: Al-Khayri, J., Jain, S., Johnson, D. (eds.) Date Palm Biotechnology Protocols Volume II. Methods in Molecular Biology, Vol. 1638. Humana Press, New York.

[17] Hasnaoui, A. M., Elhoumaizi, A., Hakkou, A., Wathelet, B., Sindic, M. (2011): Physicochemical characterization, classification and quality evaluation of date palm fruits of some Moroccan cultivars. - J. Sci. Res. 3(1): 139-149.

[18] Hobani, A. I., Thottam, A. N. M., Ahmed, K. A. M. (2003): Development of a neural network classifier for date fruit varieties using some physical attributes. - Agric. Res. Cent. King Saud Univ. Res. Bul. 126: 5-18.

[19] Idris, T. I. M., Hussein, F. A., Said, A. E., Elsadig, E. H. (2014): Evaluation of some dry seedling date selections from the Northern State, Sudan. - Sudanese Journal of Agricultural Sciences 1: 30-35.

[20] Kassem, H. A. (2012): The response of date palm to calcarous soil fertilization. - Journal of Soil Science and Plant Nutrition 12(1): 45-58.

[21] Little, T. M., Hills, F. J. (1972): Statistical methods in Agricultural Research. University of California, Davis.

[22] Liu, Y. Z., Deng, X. X. (2007): Citrus breeding and genetics in China. - The Asian Australian J PI Sci Biotech 1: 23-28.

[23] Mortazavi, S. M. H., Azizollahi, F., Moalemi, N. (2015): Some quality attributes and biochemical properties of nine Iranian date (Phoenix dactylifera L.) cultivars at different stages of fruit development. - International Journal of Horticultural Science and Technology 2(2): 161-171.

[24] Nasir, M. U., Hussain, S., Jabbar, S., Rashid, F., Khalid, N., Mehmood, A. (2015): A review on the nutritional content, functional properties and medicinal potential of dates. Science Letters 3(1): 17-22.

[25] Naz, S., Shahzadi, K., Rashid, S., Saleem, F., Zafarullah, A., Ahmad, S. (2014): Molecular characterization and phylogenetic relationship of different citrus varieties of Pakistan. - J Animal PI Sci 24: 315-20. 
[26] Omaima, M., Hafez, Malaka Saleh, A., Ashour, N. E., Mostafa, E. A. M., Naguib, M. M. (2015): Evaluation of some pollen grain sources on yield and fruit quality of samany date palm cv. (Phoenix dactylifera L.). - Middle East Journal of Agriculture 4(1): 27-30.

[27] Popenoe, P. (1973): The Date Palm. - Field Research Projects Coconut Grove, Miami, Florida.

[28] Purayil, F. T., Robert, G. A., Gothandam, K. M., et al. (2018): Genetic variability in selected date palm (Phoenix dactylifera L.) cultivars of United Arab Emirates using ISSR and DAMD markers. - 3 Biotech 8: 109.

[29] Qadri, R. W. K., Waheed, S., Haider, M. S., Khan, I., Naqvi, S. A., Bashir, M., Khan, M. M. (2016): Physiochemical characterization of fruits of different date palm (Phoenix dactylifera L.) varieties grown in Pakistan. - The Journal of Animal \& Plant Sciences 26(5): 1268-1277.

[30] Riad, M. (1993): The Date Palm Sector in Egypt. - In: Ferry, M., Greiner, D. (eds.) Le palmier dattier dans l'agriculture d'oasis des pays méditerranéens. Options Méditerranéennes: Série A. Sémin aires Méditerranéens; n. 28. CIHEAM, Zaragoza, pp. 45-53.

[31] Sami, S. A, Ebtissam, H. H., Samer, E. M., Hanaiya, A. E. (2004): Genomic diversity in date palm (phoenix dactylifera L.) as revealed by AFLPs in comparison to RAPDs and ISSRs. - Arab J. Biotch. 8(1).

[32] Sedra, H., Lashermers, P., Trouslot, P., Combes, C., Hamon, P. (1998): Identification and genetic analysis of date palm (Phoenix dactylifera L.) varieties from Morocco using RAPD markers. - Euphytica 103: 75-82.

[33] Snedecor, G. W., Cochran, W. G. (1980): Statistical Methods. $6^{\text {th }}$ Ed. - J. B. H. Publishing Comm., Oxford.

[34] Taain, D. A. (2013): Study on physico-chemical and physiological characteristics of date palm fruits (Phoenix dactylifera L.) cv. Um-aldehin. - Pakist. J. Agri. Sci. 50(1): 1-5.

[35] Youssef, M. K. E., Abou-El-Hawa, S. T., Seleim, M. A., Ramadan, B. R. (1998): Evaluation of chemical composition of various types of Upper Egypt dates. - Assiut Journal of Agricultural Sciences 29(3): 33-52.

[36] Zehdi, S. L., Sakka, H. L., Rhouma, A., Ould Mohamed Salemy, A., Marrakchi, M. L., Trifi, M. L. (2004): Analysis of Tunisian date palm germplasm using simple sequence repeat primers. - African J. of Biotech. 3(4): 215-219.

[37] Zeinab, A. A, Gada, A. A, El- Kafrawy, T. M., Essam, A. M. (2014): Physicochemical and molecular genetic evaluation of selected dry date palm seedling trees. - Middle East J. Appl. Sci. 4(4): 931-941. 